\title{
安全性からみた斜路のすべりの評価方法に関する研究 STUDY ON THE EVALUATION METHOD ON SLIPPERINESS OF INCLINED FLOORS FROM A VIEWPOINT OF SAFETY
}

\author{
小野英哲*, 北山 大**, 高橋宏 樹*** \\ Hidenori ONO, Hiroshi KITAYAMA and Hiroki TAKAHASHI
}

\begin{abstract}
This study presented the method to evaluate the slipperiness of inclined floois from a viewpoint of safety.

We grouped inclined floors into two classes from the condition to set foot on them.

Then, in order to make the evaluation scales of slipperiness, we carried out the sensory tests on inclined floors.

Next, we proved that the slip resistances which were composed of C. S. R and gradient corresponded to the evaluation scales.

As a result, the method to evaluate the slipperiness of inclined floors was presented as the method to measure the slip resistances and the evaluation indices.
\end{abstract}

Keywords : inclined floors, slipperiness, safety, evaluation method 斜路, すべり, 安全性, 評価方法

\section{1. 序 論}

近年屋内外において，キャスター走行の確保，つまず きや転落発生要囚の排除などの観点から段差や階段を設 置するかわりに斜路を設ける場合が以前に比べ多くなっ てきている。

一方，斜路においては，水平な床に比べ同一すべり抵 抗をもつ仕上面でも, 走行時に仕上面方向に与える荷重 が大きくなるためよりすべりやす、くなる，動作時の姿勢 がより不安定になりやすいなどの理由から，すべりに起 因する傷害事故が後を絶たず，早急に安全性からみた斜 路のすべりの評価方法を検討する必要があるといえる。

筆者の一部らは，これまで水平な床および階段を対象 としてすべり抵抗を测定できるすべり試験機を開発する とともに，用途や動作ごとに安全性，快適性からみたす ベりの評価方法を提示している1 ${ }^{13113}$ 。しい, 適用範团 が水平な床および階段に限られているため, 研究成果を 直ちに斜路のすべりの評洒に適用できない状況にある。

本研究は, 水平な林におけるすべりの研究成果の斜路 への適用を試みるとともに, 安全性からみた斜路のすべ りの評価方法を検討したものである。

\section{2. 研究の目的と範囲}

本研究の目的は, 走行時の斜路のすべりの程度を, 実 情と高い相関をもって表示できるすべり試験方法につい て考究し，さらに斜路のすべりを評価できる方法を確立 することにある。

評価する観点は斜路において最も重要な安全性とし, 水平な床で安全性とともに重要となっている快適性は斜 路では一般に距離が短く大きな問題とはならないため, 除外することとする。

また，本研究では斜路のすべりの評価方法を究明する ことに目的を限定していることから，斜路に用いられる 仕上材料の諸性質とすべりの関係の提示, すべりからみ て安全な仕上材料の開発，提示などは範囲外とする。

なお，評価方法を確立できれば，より速やかにかつ合 理的にすべりからみて安全な仕上材料の開発，提示を行 えると考えていることを付記する。

\section{3. 既往の研究}

水平な休のすべりの評価方法に関する研究成果は国内 外において数多く発表されているが, 人間が動作する場 合の斜路のすべりについての研究例，規格例は少なく，

\footnotetext{
* 東京工業大学工学部建築学科 教授. 工博

** 株式会社フジタ (当時東京工業大学 大学院生). 工修

*** 東京工業大学工学部建築学科 助手・体育修
}

Prof., Dept. of Architecture and Building Engineering, Faculty of Engineering, Tokyo Institute of Téchnology, Dr. Eng.

Fujita Corporation, M. Eng.

Research Assoc., Dept. of Architecture and Building Engineering, Faculty of Engineering, Tokyo Institute of Technology, M. Phys. Educ. 
おもな例としては以下が挙げられる。

宇野らは斜路の傾斜角度について，床のすべりに影響 を及ぼす要因のひとつとして考察している ${ }^{14)}$ 。坂田らは 斜路を昇降する際の必要摩擦係数について考察してい る $^{15 !}$ 。独国障害保険協会は, DIN 51097 に基づき水廻 りに用いられる傾斜した床のセラミック製床仕上材料に ついて, 素足が需れた状態で歩行する際に危険と感じる 角度を求め, 角度ごとに適切な使用条件を設定してい $る^{16)}$ 。

しかしこれらは，仕上材料を媒体とした定性的な評価 にとどまっていること, 斜路の傾斜とすべりの関係を連 続的に把握する方法を提示していないこと，限定された 状況でのすべりを対象としていること, さらに規格に至 るまでの研究経緯が明らかにされていないことなどの理 由から，すべり抵抗や傾斜を連続する要因として取り込 んだうえで斜路のすべりの定量的評価方法を確立するこ とを目的とする本研究にとって，断片的知見として参考 にはなるが直接の適用などは無理といえる。

\section{4. 研究方法の概要}

研究方法の概要はつぎのとおりである。

（1）斜路のすべりの程度を人間の判断を用いて尺度化 し，すべり評価尺度として定量的に把握する。

ここで, 斜路のすべりの程度などを定める方法として は, 斜路における足の動きを媒体とするなどの方法も考 えられるが, 動く, 動かないなどの単純な現象からは多 くの情報を得られないことが明確なので, 本研究では央 際に人間が走行するときのすべりの判断を媒体として尺 度を構成することとする。なお，人間の判断を媒体とす ることの有効性は筆者の一部らの既往の研究で実証済み である11-13)。

（2）すべり評価尺度を表示できるすべり抵抗の測定方 法を求める。

（3）すべり評価尺度とすべり抵抗值の対応から,すべ りの評価指標および評価方法を提示する。

\section{5. 安全性からみた斜路のすべり評価尺度の構成}

\section{1 斜路のすべり評価尺度構成のための検査}

斜路のすべり評価尺度を構成するための検査の概要を 表一1に示すとともにおもな事項について説明を加え る。

\section{（1）構成する尺度および尺度構成手法}

構成する尺度は，斜路において最も重要な安全性から みたすべり評価尺度とした。

尺度構成手法としては, 試料斜路のすべりを表一1に 示す判断範ちゅうを用いて絶対判断した結果から尺度を 構成する系列範ちゅう法年を用いることとした。

なお本研究では, 斜路における歩行および足部の接触
状況から，斜路を以下のように2つに分類し，それぞれ について尺度を構成することとした。

・数歩以上の歩行動作を行える長さをもち，履物全体あ るいは一部が接触する斜路 (以降, 長斜路と呼ぶ)

・履物全体が接触する長さをもたず，おもにかかと部分 で接触する可能性がある段差に近似した斜路（以降，短 斜路亡呼了:

\section{（2）試料斜路の概要 \\ 試料斜路の概要を表一1 および図一1に示す。}

表一1 斜路のすべりの安全性に関する検査の概要

\begin{tabular}{|c|c|c|c|c|}
\hline 試科 & \multicolumn{3}{|c|}{ 畏斜路 } & 短斜路 \\
\hline 構成尺度 & \multicolumn{4}{|c|}{ 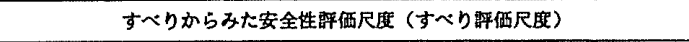 } \\
\hline 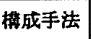 & \multicolumn{4}{|c|}{ 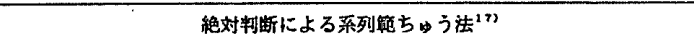 } \\
\hline 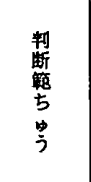 & \multicolumn{4}{|c|}{ 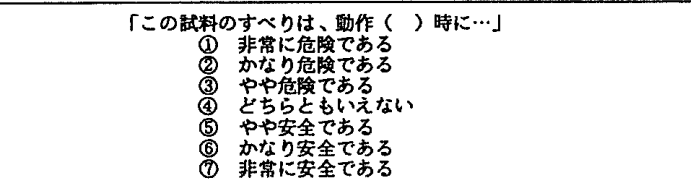 } \\
\hline 動作 & \multicolumn{3}{|c|}{ 上り、方向蛙换、下り } & 下ク(かかとで跍む) \\
\hline 履物 & 柛士放 & *紳士蜼(体装) & M化-N & 种士靴 \\
\hline 梌查只 & 成人男子10名 & 成人男子10名 & 成人女子10名 & 成人男子10名 \\
\hline 試料寸法 & \multicolumn{3}{|c|}{ 蝠750 $\mathrm{mm} \times$ 長さ1.800mm } & 幅750m $\times$ 展さ150m \\
\hline 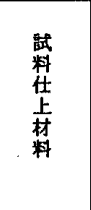 &  & $\begin{array}{l}\text { 左毁 } \\
1,3,5\end{array}$ & $\begin{array}{l}\text { Dうち、 } \\
\text { 7.9 }\end{array}$ & $\begin{array}{l}\text { 左記のうち } \\
1 、 3 、 5 、 6 、 7 、 9\end{array}$ \\
\hline 佰料角度 & $0^{\circ}, 5^{\circ}, 10^{\circ}, 15^{\circ}, 20^{\circ}, 30^{\circ}$ & $0^{\circ}, 5^{\circ}, 10^{\circ}$ & $15^{\circ}, 20^{\circ}$ & $5^{\circ} 15^{\circ} 20^{\circ}, 30^{\circ}, 40^{\circ}, 45^{\circ}$ \\
\hline 試料数 & $9 \times 6=54$ & $5 \times 5$ & $=25$ & $6 \times 6=36$ \\
\hline
\end{tabular}

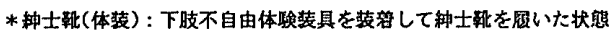
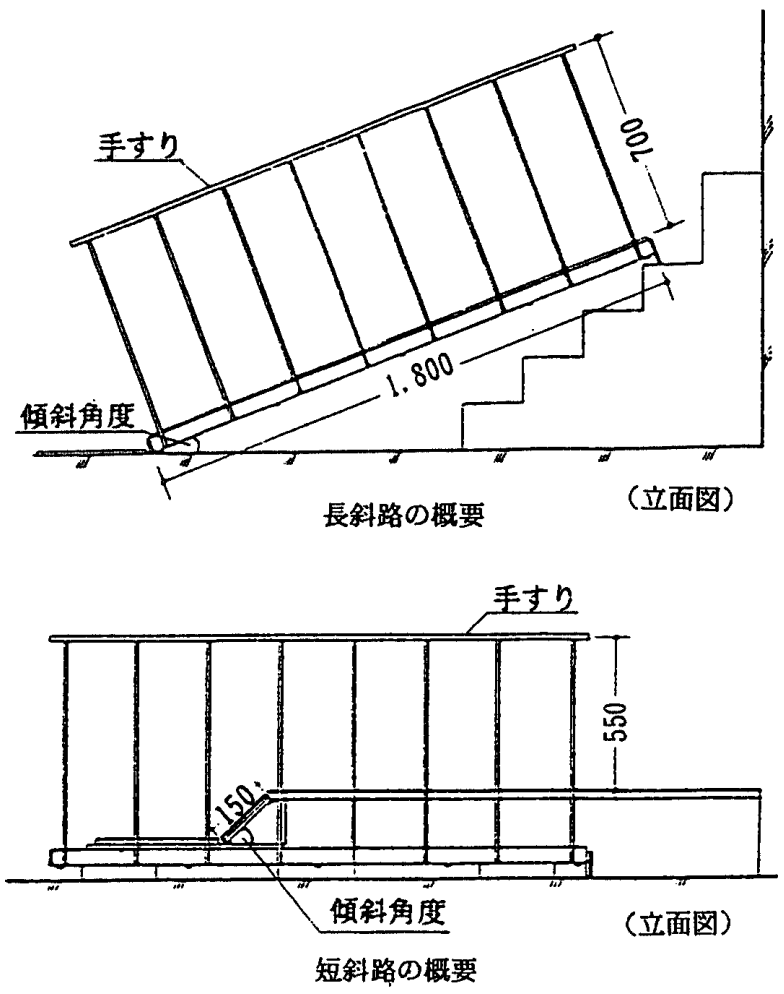

図一1 試料斜路の概要 
試料はすべり性状の異なる 9 種類の床仕上材料を貼付 した斜路で，所定の動作を行うのに十分な大きさとし， 検查時の安全性を確保するため手すりを設置している。

また，試料斜路の傾斜角度は，それぞれ実際の斜路の 傾斜角度の範囲を十分包含し，かつ予備実験により，設 定する動作が可能であると思われる範囲とした。

なお，検查の組合わせごとに試料数が異なるのは長斜 路での多くの試料数による検查の結果から，試料数をそ れぞれ必要罗少限にすることの妥当性を確認できた範囲 において，検查員の負担などの観点から試料数を減じた ことによる。

\section{（3）動作の設定}

長斜路では歩行による上り, 方向転換, 下りの 3 種類, 短斜路の場合は最も危険と思われる下りのみでかつ，斜 路をかかと部分だけで踏む動作に限定した。

なお，いずれの場合にも手すりを用いないことを原則 としたが;やむを得ない場合は用いてもよいこととした。 (4) 履物の選定

長斜路の場合は屋内外で一般的に用いられる紳士靴, 八イヒールとし, さらに身体障害者や老人などのように 身体条件が悪い人々の判断を推察するため一部の検查に おいて下肢不自由体験装具 ${ }^{18)}$ (健常者の足首の関節を固 定することにより下肢の不自由な人のひとつの状態を再 現する装具）を装着した場合の判断も参考として求める こととした。短斜路の場合は, 所定の動作を行える観点 から紳士靴のみとした。

また，履物および試料休の表面性状を一定に保持し， つねに同じすべり抵抗を具現する観点から，履物底に綿 ブロード (40 番) を随時貼ることとした。

\section{(5) 検查員の選定}

検査員としては，健常な成人男子 10 名（年踰 21 才 31 才）と成人女子 10 名 (年秢 21 才 28 才), 計 20 人 を選定した。

\section{2 検査の経過および結果}

5.1 の条件で検査を実施し，基礎デー夕を得た。 検査の結果得られた基礎データの分散分析結果を表一

表一2 分散分析の結果

\begin{tabular}{|c|c|c|c|c|c|c|c|c|}
\hline \multirow{2}{*}{ 斌 } & \multirow{2}{*}{$\begin{array}{l}\text { 動 } \\
\text { 作 }\end{array}$} & \multirow{2}{*}{$\frac{\text { 履 物 }}{\text { 項 目 }}$} & \multicolumn{2}{|c|}{ 紳士靴 } & \multicolumn{2}{|c|}{ 种士靴(体装) } & \multicolumn{2}{|c|}{ ハイヒール } \\
\hline & & & 分散比 & 奇与率 & 分散比 & 奇与率 & 分散比 & 奇与率 \\
\hline \multirow{6}{*}{$\begin{array}{l}\text { 長 } \\
\text { 斜 } \\
\text { 路 }\end{array}$} & 上 & 主効果 & $37.1 * *$ & $67.9 \%$ & 16. $2 * *$ & $46.7 \%$ & $25.0 * *$ & $68.0 \%$ \\
\hline & $\eta$ & 個人差 & $41.9 * *$ & $13.0 \%$ & $19.8 * *$ & $1.6 \%$ & 6. $0 * *$ & $4.9 \%$ \\
\hline & \multirow{2}{*}{$\begin{array}{l}\text { ※ } \\
\text { 䡆 } \\
\text { 換 }\end{array}$} & 主勃果 & $.35 .8 * *$ & $67.0 \%$ & $18.8 * *$ & $49.1 \%$ & $31.7 * *$ & $69.0 \%$ \\
\hline & & 個人美 & 42. $0 * *$ & $13.4 \%$ & 22. $7 * *$ & $22.4 \%$ & 10. 1** & 7. $7 \%$ \\
\hline & \multirow{2}{*}{$\begin{array}{l}下 \\
\eta\end{array}$} & 主効果 & $36.6 * *$ & $65.7 \%$ & 22. & $48.7 \%$ & $32.1 * *$ & $70.7 \%$ \\
\hline & & 個人美 & $50.5 * *$ & $15.5 \%$ & $33.8 * *$ & $27.8 \%$ & 7. $7 * *$ & $5.8 \%$ \\
\hline \multirow{2}{*}{$\begin{array}{l}\text { 短 } \\
\text { 斜 } \\
\text { 路 }\end{array}$} & F & 主効果 & $54.5 * *$ & $80.7 \%$ & \multirow{2}{*}{\multicolumn{3}{|c|}{$\begin{array}{l}\text { ※転換: 方向転換 } \\
\text { **危险率 } 1 \% \text { で有 }\end{array}$}} & \\
\hline & b & 個人差 & 10. $9 * *$ & $3.9 \%$ & & & & \\
\hline
\end{tabular}

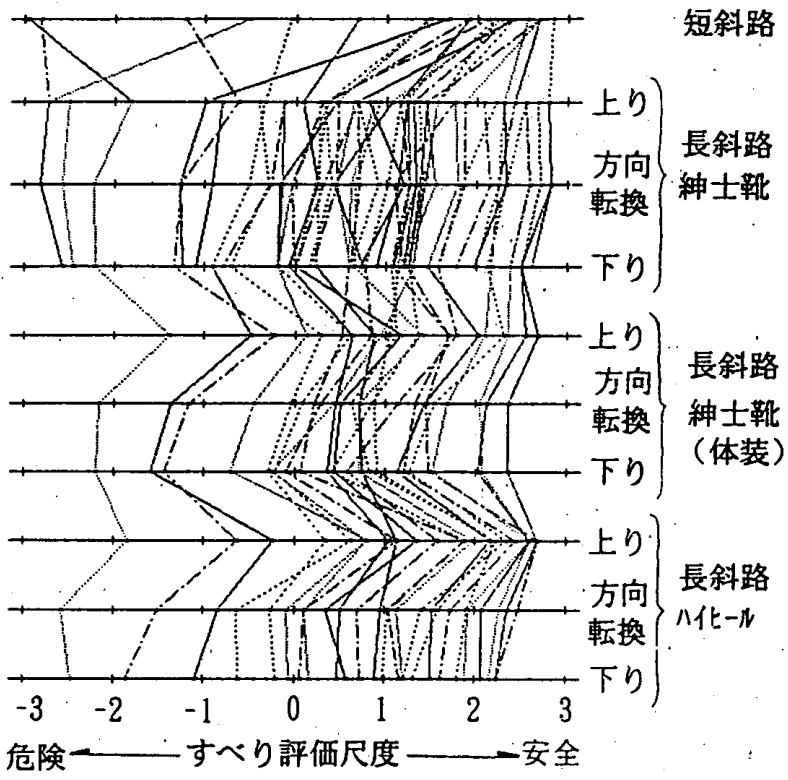

図一2 尺度線図

2 に示す。

いすれれの結果においでも主効果の分散比が高度に有意 でありかつ寄与率も高いことから, 試料のすべりに有意 な差があること，検查自体が有効であることがわかる。 また個人差の分散比が有意となっているが，寄与率がい ずれも主効果と比較して非常に低いことから，構成され る尺度は個人差が内包されるものの十分有効といえる。

\section{3 斜路のすべり評価尺度の構成および考察}

検査の結果得られた基礎デー夕を用い，尺度構成理 論 $^{171}$ に従いすべり評価尺度を構成した。

·図一-2に構成したすべり評価尺度值をそれぞれの尺度 線図上に示す。

図から，履物，動作にかかわらず長斜路のすべりの評 価の序列はほぼ一致していることがわかる。つまり，代 表的な一つの方法によって得られるすべり抵抗ですべて の場合の長斜路のすべり評価尺度を表示できる可能性を 見いだすことができる。

一方, 短斜路と長斜路のすべりの評価の序列は一致し ていないことが明らかで，短斜路のすべり抵抗の測定は かかと部分と斜路との接触状況などを考慮したうえで， 長斜路の場合とは別に検討する必要性を見いだすことが できる。

\section{6. 斜路のすべり抵抗の測定およびすべり抵抗值とすべ り評価尺度との対応の検討}

\section{1 長斜路の場合}

すべり抵抗の測定には，筆者の一部らが開発し JIS A 5705 に規定された図一3に示すすべり試験機，O-Y • $\mathrm{PSM}^{11-31}$ を用いることとした。

本試験機は，実際の履物底を切り取りすべり片台座に 貼りつけすべり片とし，重錘により鉛直荷重を載荷した 
すべり片を, 斜め上方に所定の荷重速度で引張り,すべ りを生じるまでの最大引張荷重を測定するもので，すべ り抵抗を表示する物理量であるすべり抵抗係数 (C.S.R) は, 最大引張荷重を重鍾による鉛直荷重 (80 kgf) で除して求めることができる。

本項では長斜路の検査で用いた履物底を切り取りすべ り片とし，各試料を水平にした状態で C.S.R を求めた。 なお，測定時には検査時と同様にすべり片底に綿ブロー ド (40 番) を随時貼付した。

長斜路のすべり評価尺度と C. S. R との関係を図一4 に示す。

図から，いずれの履物，動作の場合もすべり評価尺度 亡 C.S.R とは傾斜角度ごとによい対応を示し，いずれ の傾斜角度においても C.S.R が大きくなると評価が安 、全側に移行すること, 傾斜角度が大きくなると評価が危

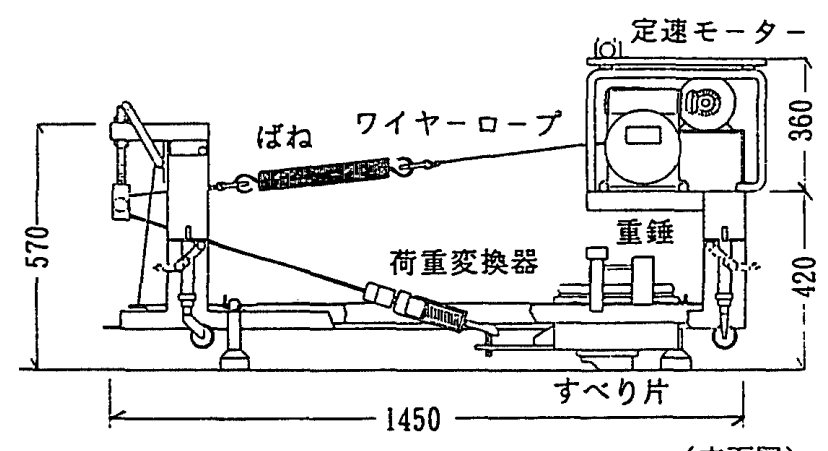

図一3 $\quad 0-Y \cdot P S M$ の概要

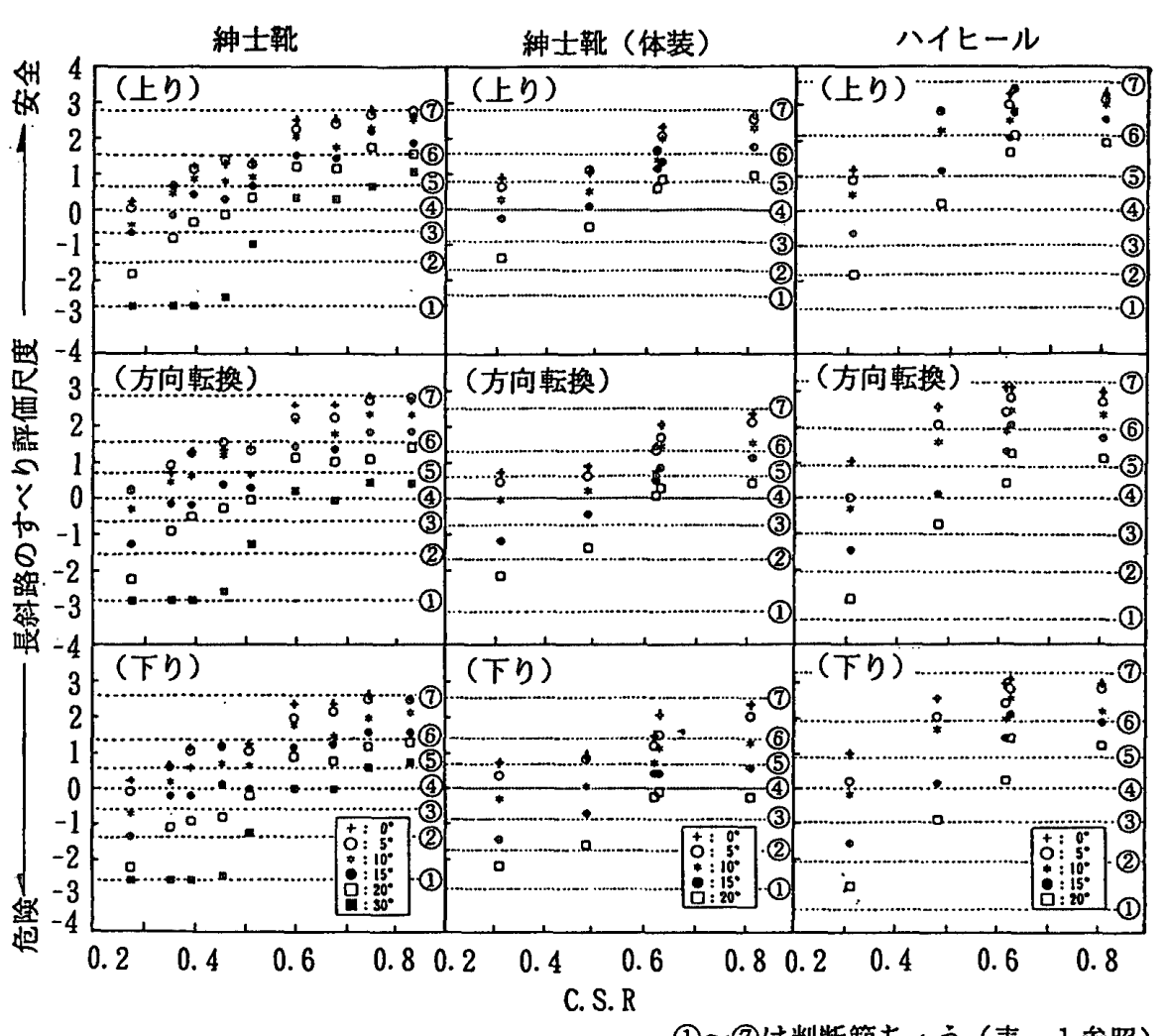

图一4 長斜路のすべり評価尺度と C. S. R との対応
険側に移行することがわかる。

ここで，任意の傾斜角度をもつ長斜路のすべりを統括 して評価するには傾斜角度を取り込んだすべり抵抗值で すべり評価尺度と対応させる必要があることから，傾斜 角度を取り込んだすべり抵抗値を設定することとした。

種々検討の結果, 傾斜角度を $\theta$ とした場合 C.S.R一 $\sin \theta$ (以降, C.S.R.LI と呼ふ）なるすべり抵抗值 を設定した。

図一5にすべり評価尺度と C. S.R・LI との対応を示 す。なお，図中破線は中心傾向を目視により判断し引い たものである。

いずれの履物，動作の場合も両者はよく対応している ことが明暸で設定した C.S.R・LI が長斜路のすべりを 表示するすべり抵抗值として十分といえる。

また，図一5から仮に「かなり安全である」の判断〔6 を許容基準とした場合の必要最小限の C.S.R・LI を必 要 C.S.R・LI として抽出した結果を図一6に示す。

図から，いずれの履物の場合も必要 C.S.R・LI が最 も小さいのは動作が上りの場合であり, 最も大きいのは 紳士靴着用時は下りの場合, 八イヒール着用時は方向転 換の場合であることがわかる。理由として，下りの場合 には進行方向に対してより大きな仕上面方向の荷重が加 わること，また八イヒールは紳士靴に比べ横方向の安定 性がより低いため方向転換時により危険性が高くなるこ となどから，いずれの場合もより大きなすべり抵抗を必 要とすることが想定される。

また，下肢不自由体験装具装 着時は他の場合に比べ必要 C.S.R・LI が大きいことがわ かる。理由として体験装具装着 時は足首の関節が固定されてい るために動作が困難となり，よ り大きなすべり抵抗を必要とす ることが想定される。このこと から, 下肢の不自由な人々が利 用する斜路のすべり抵抗は他の 場合に比べより大きくしなけれ ばならないことがわかる。

6.2 短斜路の場合

短斜路においては水平な床の 場合と動作および履物の斜路へ の接触状況が大きく異なること から，O-Y.PSM を用いる場 合の 2 つの条件を多様にしてす ベり抵抗の測定を行った結果か ら最も妥当な条件を設定するこ

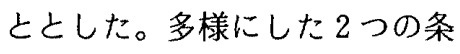
件は以下の亡おりである。 


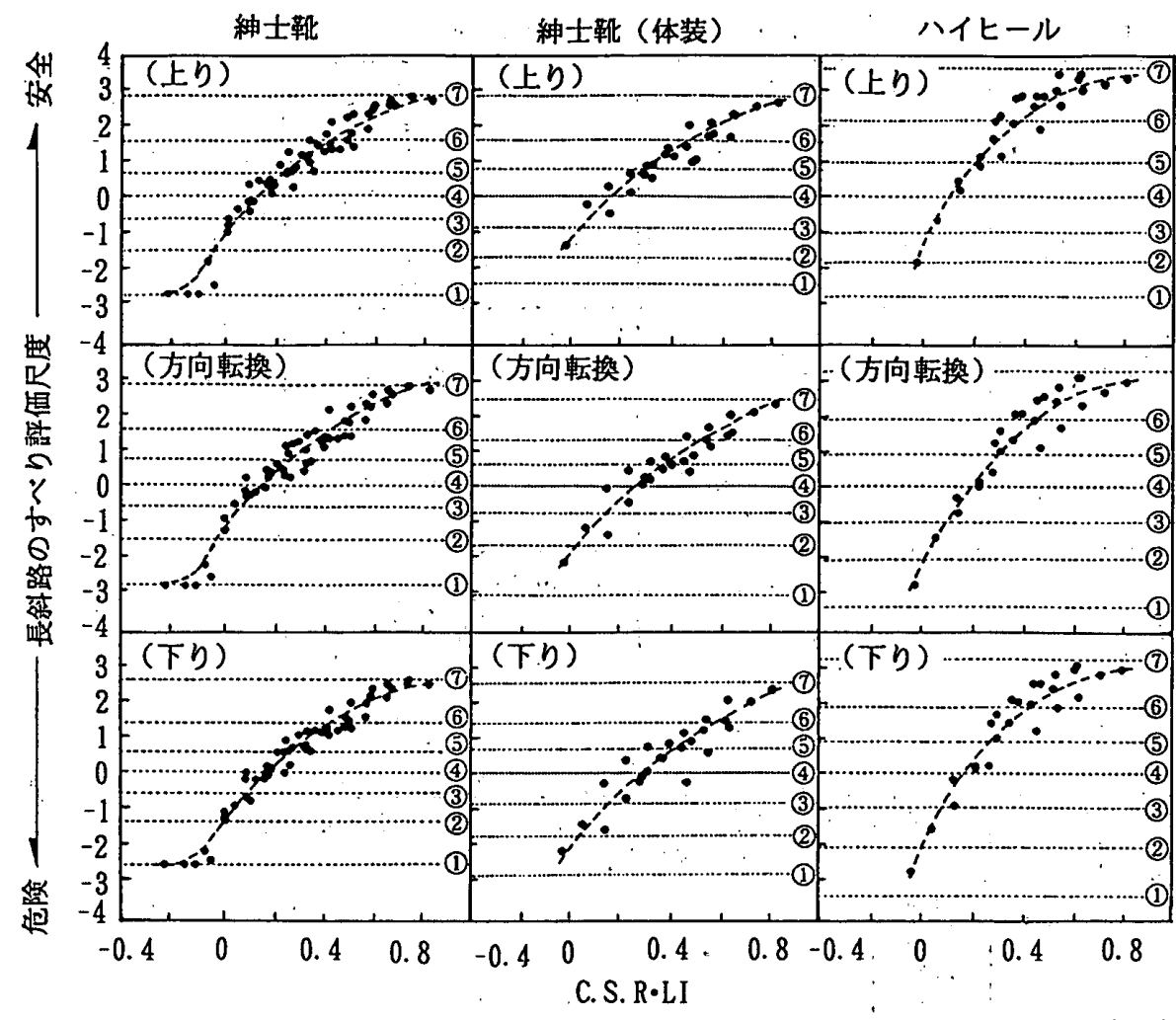

図一5 長斜路のすべり評価尺度と C.S.R・LI との対応

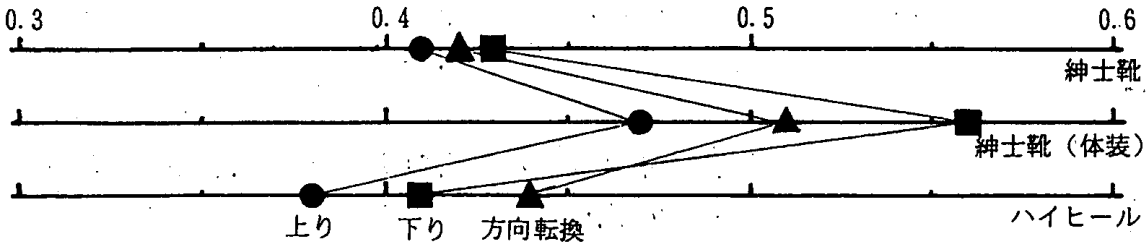

図一6「かなり安全である」の判断6を許容基準とした場合の必要 C.S. R・LI

・すべり片について

短斜路の場合，検査に用いた 履物のかかと部分を切り取りす ベり片とするのは困難なことか ら，同一硬度をもつ合成ゴムを 用いて，短斜路における履物の 接触状況とほぼ近似する状態を 作り出すことを主眼にすべり片 を製作した。すなわち，図一7 および表一3に示す接地長さ (L) の異なる 6 種類のすべり片 を用い，すべり評価尺度と最も 対応のよいすべり抵抗が得られ る場合のすべり片を採用するこ ととした。ここで接地部分を 2 箇所に分割したのは，すべり抵 抗测定時の $\mathrm{O}-\mathrm{Y} \cdot \mathrm{PSM}$ の重鍾 の前後方向の安定性を確保する ためである。なお，測定時には 検查時と同様にすべり片底に綿 ブロード (40 番) を随時貼る こととした。

以上の条件の重鍾およびすべ り片を用いて表一3に示した場 合のすべり抵抗を測定した。な お，灾落している組合わせは検 討の途中において測定の必要が ないと判断されたものである。

短斜路のすべり評価尺度とそ

\section{・重鍾重量について}

短斜路の場合，かかと部分で斜路に与える荷重の諸性 状が水平な床の場合と大きく異なることが想定されたた め，重錘重量 $(W)$ を表一 3 に示す 3 段階とし，すべり評 価尺度と対応のよいすべり抵抗が得られる場合の重錘重 量を採用することとした。

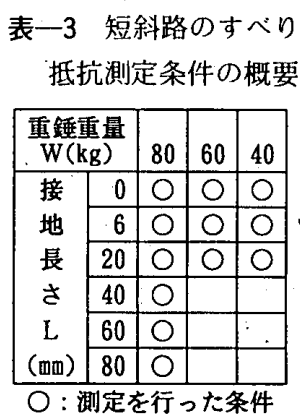

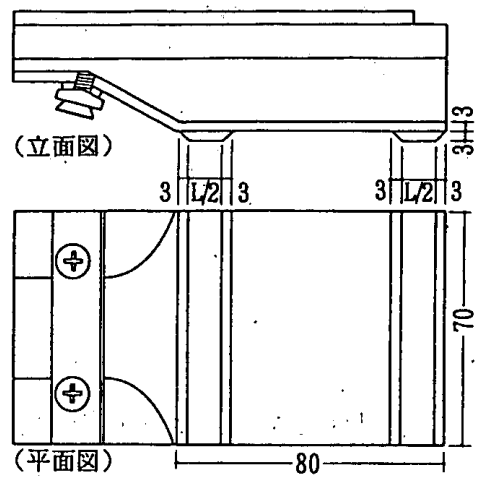

图一7、短斜路のすべり抵抗測定に用いた すべり片の概要
れぞれの条件下で測定したすべり抵抗值の関係を図一8 に示す。ここで，すべり抵抗值はそれぞれの条件での最 大引張荷重を重鍾重量で除した值で表示している。

図から，いずれの条件の場合もすべり抵抗值が大きく なると評価が安全側に移行し，傾斜角度が大きくなると 評価が危険側に移行するおおよその傾向がうかがえる。

ここで，任意の傾斜角度をもつ短斜路のすべりを統括 して評価するには傾斜角度を取り込んだすべり抵抗值で すべり評価尺度と対応させる必要があることから，長斜 路の場合と同様に，すべり抵抗值から $\sin \theta$ をひいた值 をすべり抵抗值（傾斜角包含）として設定し，対応を検 討することとした。

短斜路のすべり評価尺度とすべり抵抗值 (傾斜角包含) との関係を図一9に示す。

図から，いずれの条件の場合もすべり評価尺度とすべ り抵抗值（傾斜角包含）のあいだには対応関係が認めら れるが，最も適当な条件を以下のように検討した。

- 重鍾重量 $W$ にういて

すべり片の接地長さ $L$ ごとにみるといずれの場合も 


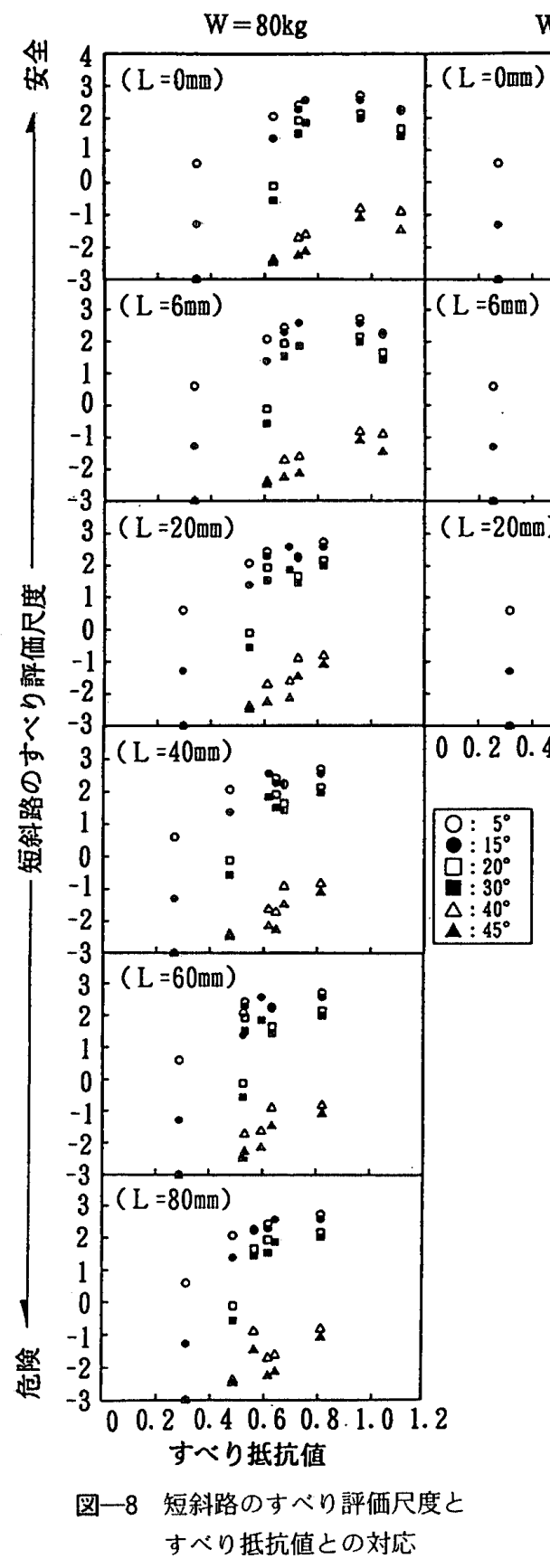

対応には重錘重量による明確な差異がないことから，

C.S.R の測定条件と同じ $W=80 \mathrm{~kg}$ が適当であると判 断した。

・すべり片の接地長さ $L$ について

$W=80 \mathrm{~kg}$ とした場合, $L=0 \mathrm{~mm}, 6 \mathrm{~mm}$ の場合はあ まりよい対応が得られず，Lが $20 \mathrm{~mm}$ 以上の場合は $L$ の増加に伴い対応が悪くなる傾向が認められることか ら, $L=20 \mathrm{~mm}$ の場合に最もよい対応が得られると判断 できる。

以上から， $W=80 \mathrm{~kg}, L=20 \mathrm{~mm}$ とした場合のすべ り抵抗值（傾斜角包含）を新たに短斜路の場合のすべり 抵抗值, C.S.R・SI (C.S.R-sin $\theta$ ) として設定した。 すべり評価尺度と C.S.R.SI との対応の詳細を図一 10 に示すが（図中破線は中心傾向を目視により判断し
$\mathrm{W}=60 \mathrm{~kg}$

$\mathrm{W}=40 \mathrm{~kg}$

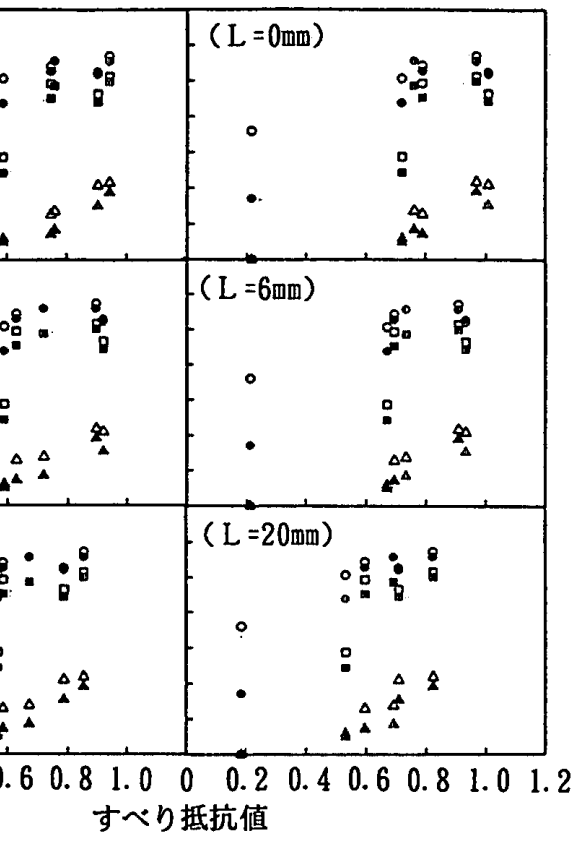

引いたものである) 両者はよく対応していることから， C.S.R・SI が短斜路のすべりを表示するすべり抵抗值 として十分であるといえる。

\section{7. 安全性からみた斜路のすべりの評価指摽および評価 方法の提示}

7.1 斜路のすべりの評価指標の提示

6.1の結果から, C.S.R・LI を長斜路のすべりを評 価するすべり抵抗值とし，図一 5 を長斜路のすべりの評 価指標として提示する。

また 6.2 の結果から，C.S.R・SI を短斜路のすべり を評価するすべり抵抗值とし，図一10を短斜路のすべ りの評洒指標として提示する。

ただし，それぞれ適用できる斜路の傾斜は本研究で採 用した傾斜角度の範囲とする。

\section{2 斜路のすべりの評価方法の提示}

本研究で提示する斜路のすべりの評洒方法および手続 きは,つぎのとおりである。

（1） O-Y·PSM を用い，長斜路の場合は実際の履物 底をすべり片として用いて求めた C.S.R，短斜路の場 合は実際のかかと部分と同一の材料を用いて $L=20 \mathrm{~mm}$ に製作したすべり片を用いて求めた C.S.R を測定す る。

（2）対象とする斜路の傾斜角度 $\theta$ を测定し $\sin \theta$ を 求め，（1）で测定した C.S.R から $\sin \theta$ をひいた値 をそれぞれ C.S.R・LI および C.S.R・SI として算出 する。 

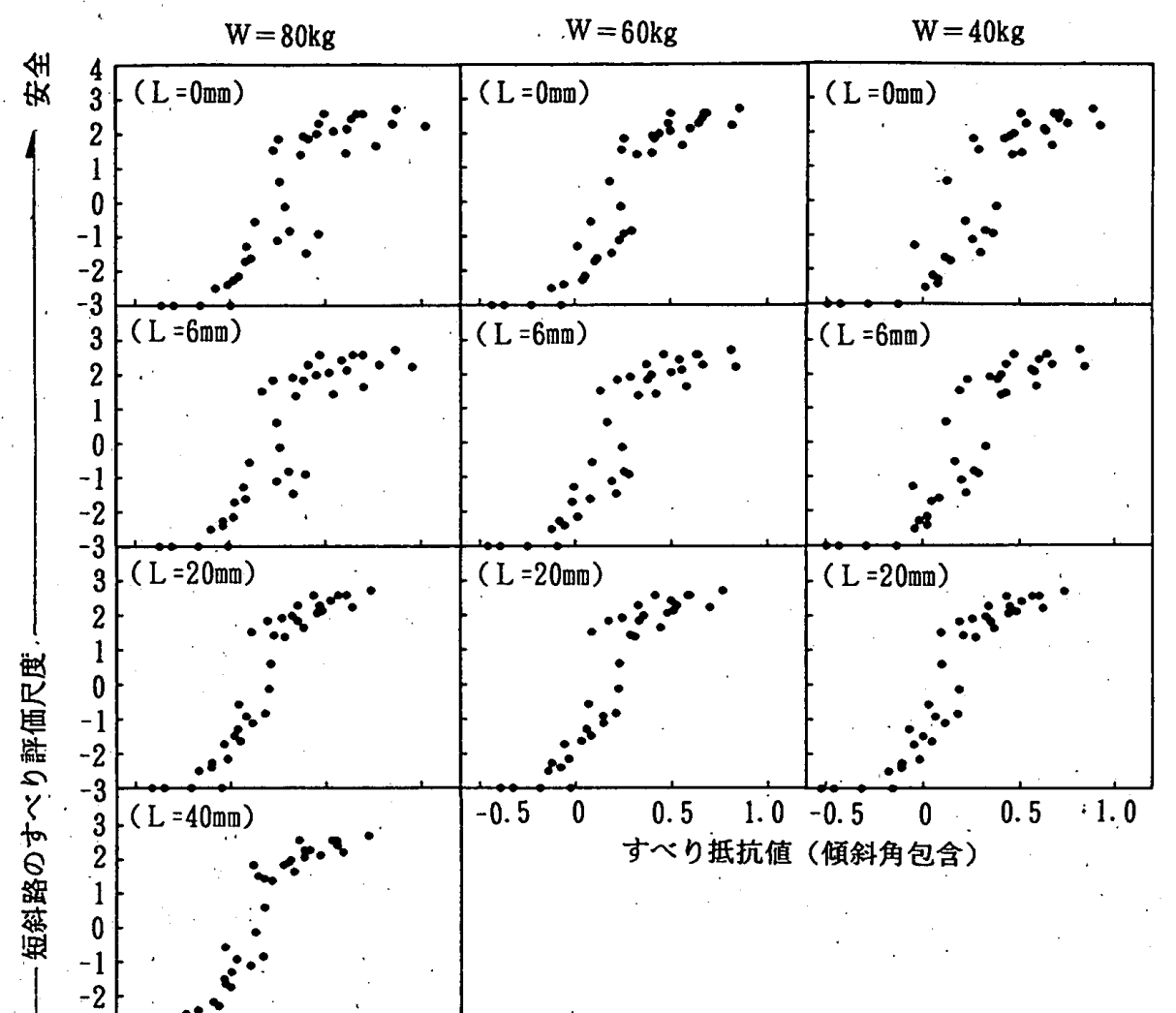

べり抵抗値（傾斜角包含）

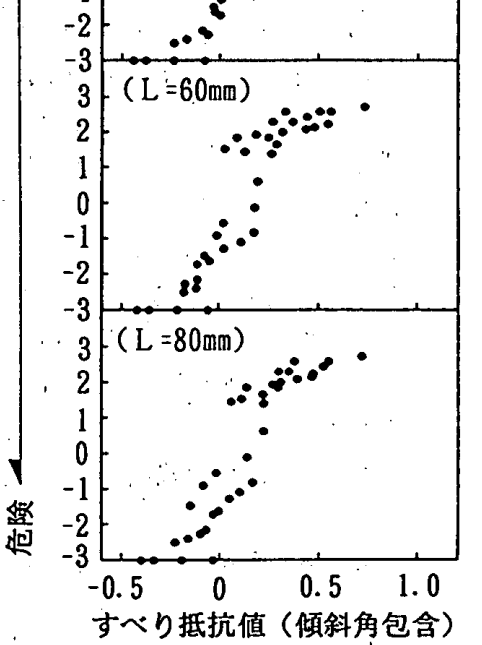

図一9短斜路のすべり評価尺度とすべり 抵抗値（傾斜角包含）との対応
（３）（2）で求めた C.S.R・LI，C.S.R・SI をそれ ぞれ図一 5 および図一10に提示した評価指標に照合し， 対象とする斜路のすべりを評価する。

なお, 本研究で対象とした人々以外の層, 履物, 動作 の評価指標はなく本質的には今後の課題となるが，無限 の課題ともいえること，またそのような層，履物，動作 の場合は頻度が非常に少ないことから，現時点では代表 的な層, 履物, 動作を対象とした本研究の成果を随時応 用して評価指標を定めても大きな問題にならないと考え る。

以上であるが, ·図一 5 および図一 10 においてすべり抵 抗の許容基準を設定することにより，必要 C.S.R・LI および必要 C.S.R・SI を求めること，さらには任意の

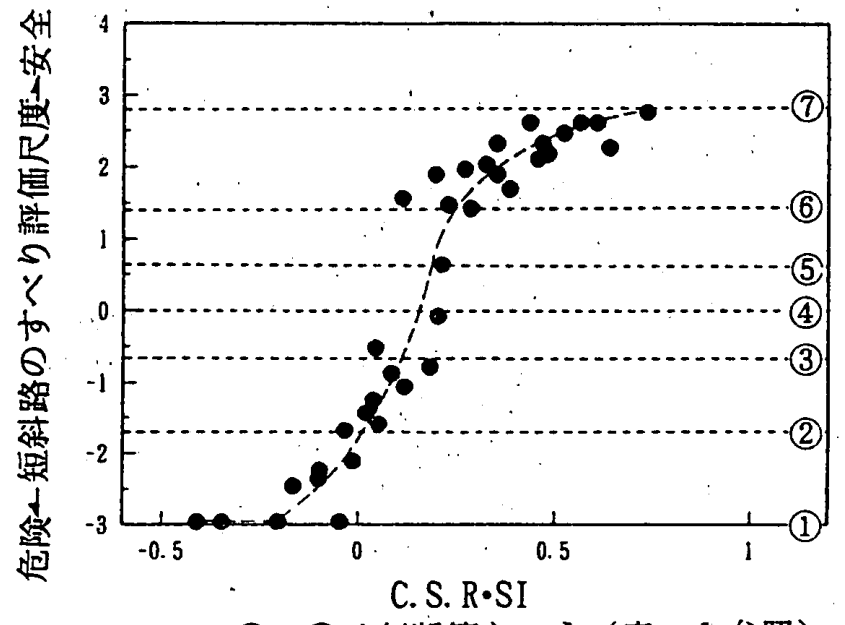

(1)〜(7)は判断範ちゅう（表一 1 参照）

図一10 短斜路のすべり評価尺度と C.S.R.SI との対応

すべり抵抗をもつ仕上材料を用いる場合の斜路の許容傾 斜角度を求めることなども可能で，本研究の成果はすべ りからみて安全な斜路を開発，選択するうえで十分有効 な知見になると考える。

\section{8. 結 論}

本研究では, 水平な休におけるすべりの研究成果の斜 路への適用を試みるとともに, 斜路の傾斜とすべりの関 係について検討した結果, 㚣全性からみた斜路のすべり に関して筆者の一部らによる水平な床におけるすべりの 評価方法を基本として, 評価指標を含む評価方法を 7 . のように提示した。 


\section{謝 辞}

本研究を進めるにあたり，下肢不自由体駼装具を貸与 していただいた積水ハウス(株)，試料を提供していた だいた床材料メーカー各社，および検查員として協力い ただいた方々に謝意を表します。なお，実験，検査の一 部を杉岡和幸君（当時日本工業大学卒研生）が担当した ことを付記します。

\section{参考文献}

1）小野英哲，宮木宗和，河田秋澄，吉岡 丹：床のすべり およびその評価方法に関する研究，その 1 研究方法お よびすべり感覚の尺度化，日本建築学会論文報告集，第 321 号, pp. 1 8, 1982 年 11 月

2）小野英哲：床のすべりおよびその評価方法に関する研究， その 2 すべり試験機の設計・試作のための基䃈的資料 の集積およびすべり試験機の基本構想, 日本建築学会論 文報告集, 第 333 号, pp. 1 7, 1983 年 11 月

3）小野英哲，河田秋澄，宮木宗和，川村清志，小西敏正， 三上貴正，橋田 浩，吉岡 丹：床のすべりおよびその 評価方法に関する研究，その 3 すべり試験機の設計・ 試作, 日本建築学会論文報告集, 第 346 号, pp. 1 8, 1984 年 12 月

4）小野英哲, 須藤 拓, 武田 清：床のすぺりの評価指標 および評価方法の提示，その 4 床のすべりおよびその 評価方法に関する研究，日本建築学会論文報告集，第 356 号, pp. 1 8, 1985 年 10 月

5）小野英哲，橋田 浩，横山 裕：スポーツサーフェイス のすべりの評価方法に関する研究，日本建築学会論文報 告集, 第 359 号, pp. 1 9, 1986 年 1 月

6）小野英哲，須藤 拓，三上貴正：安全性からみた階段の すべりの評価方法に関する基礎的考察，その 1 女全性 からみた陼段のすべりの評価方法に関する研究，日本建 築学会論文報告集, 第 362 号, pp. 1 10, 1986 年 4 月

7）小野英哲, 武田 清, 永田久雄：階段各部位のすべり抵 抗の測定方法，その 2 安全性からみた階段のすべりの 評価方法に関する研究，日本建築学会論文報告集，第 373 号, pp. 19 26, 1987 年 3 月

8）小野英哲，武田 清，三上貫正，大野隆造：安全性加的 みた階段のすべりの評価方法の提示，その 3 安全性か
らみた階段のすべりの評価方法に関する研究，日本建築 学会論文報告集, 第 383 号, pp. 1 7, 1988 年 1 月

9）小野英哲，上野静二，横山 裕，大野隆造，三上貫正： 安全性からみた浴室床および浴槽床のすべりの評価方法 に関する研究，その 1 すべり抵抗の测定方法の設定お よび浴槽縁断面寸法の設定, 日本建築学会論文報告集, 第 384 号, pp. 26 33，1988 年 2 月

10）小野英哲, 三上蛽正, 大野隆造, 横山 裕, 上野静二, 高木 直：安全性からみた浴室床および浴槽床のすべり の評価方法に関する研究，その 2 すべりの評価指標の 提示および評価方法の提示, 日本建築学会論文報告集, 第 387 号, pp. 1 7, 1988 年 5 月

11）小野英哲，高木 直，上野静二，大野隆造，三上貫正， 横山 裕, 武田 清：建築物床のすべり抵抗の測定方法 の標準化に関する研究 土砂・ほこりの代替媒介物の提 示, 日本建築学会大会学術講演梗概集 A, pp. 581 582, 1986 年 8 月

12）小野英哲，高木 直，三上貴正，横山 裕：建築物床の すべり抵抗の測定における媒介物の標準化に関する研究 水類, 油類, 洗剤類の代替媒介物の提示, 日本建築学会 大会学術講演梗概集 A, pp. 711 712，1987 年 10月

13）北山 大，小野英哲，横山 裕，三上貴正，高橋宏樹： 建築物林のすべり抵抗の測定における媒介物の標準化に 関する研究 土足床を対象とした水類の新たな代替媒介 物及びその介在量の提示, 日本建築学会大会学術講演梗 概集 A, pp. 103 104，1992 年 8 月

14）宇野英隆，直井英雄，遠藤传宏：床の状態がすべりに及 ぼす影響について, 日本建築学会大会学術講演梗概集, pp. $615 \sim 616,1973$ 年 10 月

15）田山茂夫, 坂田種男：斜路の安全に関する研究, 日本建 筑学会大会学術講演梗概集，pp. 859 860，1981 年 9 月

16) DIN 51097 "Bestimmung der rutschhemmenden Eigenschaft"

17） J.P. ギルホード，秋重義治監訳：精神測定法，培風館， 1964 年

18）川村次郎，溝淵隆司，後藤掌明：健常者がからだの不自 由を体験する装具 (体験装具)，第 7 回日本義肢装具学会 学術大会, プログラム抄録集, 1991 年 3 月

（1992 年 12 月 9 日原稿受理，1993 年 3 月 25 日採用決定） 